\title{
Taman Botani Boyolali Dengan Pendekatan Fun Design Sebagai Pusat Wisata Edukasi Botani
}

\author{
ATIKA DWI HARJANTI ${ }^{1}$ \\ PROGRAM STUDI ARSITEKTUR \\ FAKULTAS TEKNIK \\ UNIVERSITAS SEBELAS MARET, SURAKARTA \\ Email : atikadwih10@gmail.com \\ OFITA PURWANI ${ }^{2}$ \\ PROGRAM STUDI ARSITEKTUR \\ FAKULTAS TEKNIK \\ UNIVERSITAS SEBELAS MARET, SURAKARTA \\ TRI YUNI ISWATI ${ }^{3}$ \\ PROGRAM STUDI ARSITEKTUR \\ FAKULTAS TEKNIK \\ UNIVERSITAS SEBELAS MARET, SURAKARTA
}

\begin{abstract}
Boyolali is one city in Indonesia with a massive growth in infrastucture development, especially in terms of public and communities space development that became urban planning goals of Boyolali city in the last five years. There are many development programs that have been planned by the goverment, one of them is the plan for building Botanical Garden as a conservation area and public space in 2016. This program is the reason why Boyolali Botanical Garden is choosen as the object design. The design of the Botanical Garden is more focused on the educational recreation purpose that implement fun learning experiences as a learning method. This method has proven to make learning new things, in this case is botany, fun and easier to understand. The architectural approach used to solve the design problems of this Botanical Garden is Fun Design approach, so the design of Botanical Garden tries to direct architectural elements toward a design that gives a pleasant and fun environment to the users because fun environment is the most conductive learning climate for non-formal education. The architectural elements that can help to form a fun environment in Fun Design approach is : Forms, Mass Arragement, Colors, Materials, Aperture and Lighting. These elements can help to create a fun learning environment by emphasizing the design decision on the impression that can be conveyed by each elements. The impression that need to be conveyed by the design to make fun learning environment among others is cheerfullness, energetic, happy, flexible, freedoom, and refreshing. One of the example is the application of bright color (such as yellow, red, blue, ect) to convey cheerfullness and energetic impression on the design.
\end{abstract}

Keywords: Botanical Garden, Education, Fun, Fun Design, Boyolali

\section{PENDAHULUAN}

Kota Boyolali merupakan salah satu kota dengan perkembangan pembangunan infrastruktur yang cukup pesat dalam kurun waktu 5 tahun terakhir, terutama dalam pembangunan fasilitas ruang publik untuk masyarakat. Pembangunan ruang-ruang publik tersebut merupakan respon pemerintah atas antusiasme masyarakat akan keberadaan ruang publik di wilayah Boyolali. Berbagai macam program pembangunan telah direncanakan 
pemerintah untuk memperbanyak jumlah ruang publik di kota Boyolali, salah satunya adalah perencanaan pembangunan Kebun Raya di desa Indrokilo, kelurahan Kemiri, kecamatan Mojosongo, Boyolali.

Program pemerintah atas perencanaan pembangunan Kebun Raya di Boyolali tahun 2016 inilah yang menjadi landasan utama dipilihnya Taman Botani sebagai objek desain.

Taman Botani yang dirancang lebih berfokus pada fungsi taman botani sebagai pusat wisata edukasi botani namun tetap memperhatikan fungsi lain seperti fungsi konservasi dan riset yang merupakan fungsi bawaan atas konsekuensi objek desain.

Dalam fokusnya sebagai pusat wisata edukasi botani, hal yang perlu dipertanyakan adalah bagaimana suatu desain dapat berpengaruh pada proses pembelajaran (learning), serta apakah suasana ruang dapat mempengaruhi proses penerimaan materi kepada subjek pembelajaran.

Di dalam buku "Toward Creative Learning Spaces", Jos Boys (2010) telah menyimpulkan bahwa suatu ruang memiliki pengaruh yang besar terhadap proses pembelajaran. Suatu ruang dapat membantu mempermudah penyerapan materi pembelajaran dengan menciptakan suasana / iklim pembelajaran (learning climate) yang kondusif.

Iklim pembelajaran yang kondusif untuk membantu proses pembelajaran adalah suasana yang menyenangkan. Suasana menyenangkan (fun) pada ruang / environment dapat membuat suasana hati subjek pembelajaran (siswa) menjadi senang sehingga mereka menjadi lebih mudah menangkap dan memproses informasi yang diberikan. Fenomena ini telah dijelaskan dalam suatu penelitian tentang cara kerja otak yang menunjukkan bahwa ketika kita dalam keadaan senang, hormon Neorotransmitter Dopamine dilepaskan dalam otak. Hormon Neorotransmitter Dopamine tersebut merangsang kinerja otak sehingga informasi yang diterima subjek mudah terserap dan diproses ke dalam otak. Judy Willis (2006) mengemukakan bahwa otak membutuhkan dopamine mengalir di dalam otak peserta didik ketika mereka belajar, sehingga "senang" harus menjadi bagian dari pembelajaran.

Selain itu, dalam penjelasan "Quantum Learning", Bobbi De Porter dan Mike Hernacki (1992), proses pembelajaran haruslah mengasyikkan (fun) dan berlangsung dalam suasana gembira sehingga pintu masuk untuk informasi baru akan lebih lebar dan dapat terekam dengan baik.

Dengan melihat hubungan antara suatu desain dan proses pembelajaran, serta pengaruh suasana menyenangkan terhadap efektifitas penyerapan informasi dalam proses pembelajaran, Taman Botani yang dirancang akan menerapkan pendekatan Desain yang Menyenangkan (Fun Design).

Dalam pendekatan Fun design, hal yang perlu diperhatikan dalam perencanaan dan perancangan desain adalah bagaimana menciptakan lingkungan yang menyenangkan (Entertaining Environment) yang memiliki nilai estetik baik (Aesthetic pleasing) namun juga tetap memperhatikan faktor keamanan (Safety). Selain itu, dalam pendekatan Fun Design, terdapat beberapa elemen desain yang dapat membantu dalam pembentukan suasana menyenangkan, antara lain adalah :(1) Pemilihan Bentuk (Abercrombie, 1984); (2) Pemilihan Material (J.Pamudji Suptandar, 1999; DK Ching, 1996); (3) Pemilihan Warna (J.Pamudji Suptandar, 1999; J Linscoten dan Drs Mansyur, 1983); (4) Penentuan Bukaan dan Pencahayaan Ruang (Sir John Soane dalam jurnal S.P Honggowidjaja, n.d); (5) Pengolahan dan penataan massa bangunan (Edmund N Bacan dalam Ching, 1996).

Berdasarkan penjelasan di atas, Taman Botani Boyolali yang dirancang akan memperhatikan kesan / impresi yang ditimbulkan tiap elemen Fun Design untuk menciptakan sarana wisata edukasi botani yang menyenangkan bagi pengunjung. 


\section{METODE}

\subsection{Penentuan Kelayakan Objek}

Penentuan Taman Botani sebagai objek rancang bangun didasari oleh adanya program pemerintah kota Boyolali tentang pembangunan Kebun Raya seluas 8 hektar di Indrokilo pada tahun 2016. Objek desain kemudian dikembangkan dengan menentukan fokus penekanan fungsi dan penyelesaian permasalahan desain sehingga diperoleh judul "Taman Botani Boyolali sebagai Pusat Wisata Edukasi Botani dengan Pendekatan Desain yang Menyenangkan (Fun Design)".

\subsection{Metoda Desain}

Gagasan ide utama yang didapat dalam proses penentuan kelayakan objek akan dianalisis bersama tinjauan data, tinjauan pustaka dan preseden untuk menghasilkan kriteria desain.

Tinjauan data yang dimaksud antara lain adalah data profil kota Boyolali serta data eksisting site/tapak yang diperoleh melalui buku paduan kota Boyolali serta survei site/tapak. Untuk tinjauan pustaka, tinjauan meliputi tentang : (1) Taman Botani, (2) Wisata Edukasi, serta (3) Fun Design dan Lima Elemen Pembentuknya. Sedangkan untuk tinjauan preseden, Brooklyn Botanical Garden, USA dipilih karena memiliki banyak variasi program edukasi botani nonformal yang tidak banyak dimiliki kebun raya yang ada di Indonesia.

Kriteria desain dapat diperoleh melalui 3 pengelompokan judul seperti berikut :

1. Wisata Edukasi sebagai Fungsi Utama.

Dari fungsi Taman Botani sebagai pusat wisata edukasi akan didapatkan pengguna (User) serta aktifitas yang akan menentukan zoning serta memunculkan kebutuhan ruang. Kebutuhan dan standar ruang ini akan menentukan Progran Ruang dalam desain.

2. Pendekatan Fun Design sebagai Solusi Pemecahan Masalah.
Dari ke lima element Fun Design (Bentuk, Material, Warna, Bukaan dan Pencahayaan, serta Tata Massa) akan didapatkan kriteria untuk menciptakan desain yang menyenangkan, terutama pada Program Bentuk dan Tampilan Taman Botani.

3. Kota Boyolali sebagai Lokasi Taman Botani.

Lokasi site taman botani telah ditentukan oleh pemerintah dikarenakan objek merupakan integrasi dari program Kebun Raya yang direncanakan oleh pemerintah kota Boyolali. Site/tapak Taman Botani yang dirancang terletak pada dusun Indrakilo, desa Kemiri, kecamatan Mojosongo, Boyolali. Kondisi eksisting tapak serta peraturan yang berlaku pada tapak akan disesuaikan dengan standarisasi zona pada perencanaan Kebun Raya (sumber :Perpres No 93 th 2011 tentang Kebun Raya Bagian ke 3 Pasal 9 nomor (2) dan tinjauan preseden Kebun Raya di Indonesia) untuk menentukan Program Tapak pada desain.

Pada metoda desain, proses 1, 2, dan 3 merupakan proses di mana kriteria desain dihasilkan dengan cara menganalisis data, teori dan preseden. Hasil yang didapat pada proses tersebut akan menghasilkan konsep perancangan Taman Botani Boyolali, yaitu : Konsep Program Ruang, Program Bentuk dan Tampilan, serta Program Tapak. Konsep perancangan tersebut nantinya akan diolah dan dikembangkan melalui transformasi desain untuk mendapatkan desain Taman Botani sebagai Pusat Wisata Edukasi Botani dengan Pendekatan Desain yang Menyenangkan (Fun Design).

\subsection{Transformasi Desain}

Transformasi Desain difokuskan pada lima elemen pembentuk Fun Design, yaitu Bentuk, Material, Warna, Bukaan dan Pencahayaan, serta Tata Massa. Kelima elemen tersebut menitik 
beratkan pada kesan/impresi yang dapat membantu terwujudnya desain Taman Botani yang menyenangkan, seperti kesan riang, bersemangat, menyegarkan, terbuka, kreatif dan sebagainya.

\section{HASIL DAN PEMBAHASAN 3.1 Peruangan}

Konsep peruangan diperoleh berdasarkan analisis pengguna (user) dan aktivitas/kegiatan. Pengguna dikelompokkan berdasarkan usia, jumlah pengunjung dan jenis kegiatan yang akan dilakukan pada Taman Botani.

Berdasarkan fungsi Taman Botani sebagai pusat wisata edukasi botani, terdapat 5 program kegiatan yang menjadi daya tarik utama Taman Botani, yaitu :

1. Discovery Garden

Usia : 6-15 th (individu/kelompok)

Kegiatan : Mendapat buku jurnal, kepingan puzzel, teka-teki dan sampel tumbuhan $\rightarrow$ mengeksplorasi dan menjelajah area Discovery Garden $\rightarrow$ mencari tumbuhan dan mencatat hasil temuan dalam jurnal $\rightarrow$ mengkonfirmasi hasil temuan pada pos Discovery Room $\rightarrow$ mendapatkan hadiah penghargaan berupa koleksi stiker jurnal.

Inspirasi : Brooklyn Botanic Garden (Sumber

www.bbg.org/collections/garden/di scovery garden).

2. Seeding's and Children's Garden

Usia : 5-12 th (Individu/Keluarga)

Kegiatan : Peserta diajarkan bagaimana cara menanam bibit tumbuhan, merawat tumbuhan (teknik penyiraman, pemupukan, clipping serta pembasmian hama dan gulma), serta membuat kompos secara langsung. Selain itu peserta dapat memanen hasil sayur dan buah pada area kebun buah untuk kegiatan tambahan.

Inspirasi : Danver Botanic Garden, (Sumber www.botanicgardens.org/programseries/seedlings) dan Brooklyn
Botanic Garden (Sumber : www.bbg.org/collections/gardens/c hildrens garden).

3. Workshop Mini-Topiary dan Ikebana Usia : Semua Usia

Kegiatan : Pelatihan pembuatan mini-topiary dan ikebana dengan memanfaatkan tumbuhan dan bunga yang diambil peserta langsung dari rumah kaca khusus (material greenhouse). Hasil pelatihan dapat dibawa pulang sebagai souvenir.

4. Herbal Garden

Usia : Semua Usia

Kegiatan : Herbal Garden adalah program pembelajaran mengenai tumbuhan yang dapat berfungsi dan berguna bagi tubuh manusia. Peserta akan diajak mengenal dan mengidentifikasi jenis-jenis tanaman herbal beserta fungsinya terhadap tubuh. Dalam program ini, peserta juga akan diajak untuk menanam serta mengolah tumbuhan tersebut menjadi ramuan herbal seperti jamu maupun teh yang dapat dinikmati bersama di bawah pengawasan pembimbing.

5. Growth Emulation Alley

Usia : Semua Usia

Kegiatan : Growth Simulation Alley adalah lorong observasi di mana peserta dapat secara langsung mengamati dan mencermati fasefase pertumbuhan pada beberapa spesies tumbuhan melalui alat bantu berupa observation box.

Inspirasi : By the Bay Garden Singapura : www.gardensbythebay.com.sg/en/a ttractions/world-of-plants/visitorinformation).

Berdasarkan analisis pengguna (user) serta kelompok kegiatannya, berikut adalah kebutuhan ruang Taman Botani Boyolali (Tabel 1):

Tabel 1. Kebutuhan Ruang

\begin{tabular}{|c|c|c|c|c|}
\hline \multicolumn{3}{|c|}{\begin{tabular}{|c|c|} 
User/ Pelaku \\
Kegiatan \\
\end{tabular}} & \multirow{3}{*}{$\begin{array}{c}\text { Kelompolk } \\
\text { Kegiatan } \\
\text { Kegiatan } \\
\text { Utama }\end{array}$} & \multirow{2}{*}{$\begin{array}{c}\begin{array}{c}\text { Kebutuhan } \\
\text { Ruang }\end{array} \\
\text { Discovery } \\
\text { Garden } \\
\end{array}$} \\
\hline 官 & & & & \\
\hline 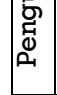 & 韋 & Aktif & & $\begin{array}{c}\text { Seeding's and } \\
\text { Children's } \\
\text { Garden }\end{array}$ \\
\hline
\end{tabular}




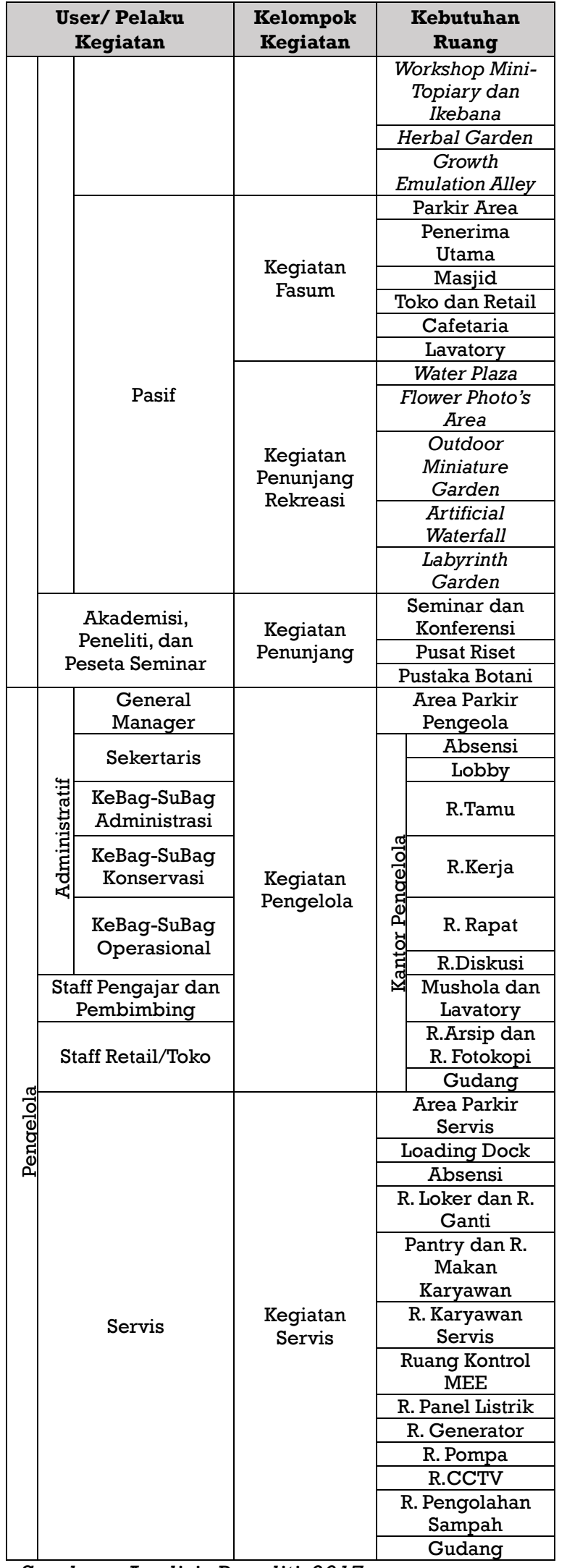

Sumber : Analisis Peneliti, 2017

\subsection{Lokasi}

Lokasi site/tapak Taman Botani Boyolali yang akan dirancang telah ditentukan oleh pemerintah kabupaten Boyolali (given), yaitu terletak pada dusun Indrakilo, desa Kemiri, kecamatan Mojosongo, kabupaten Boyolali dengan luas kurang lebih sekitar 8 hektar.

Lokasi site Taman Botani Boyolali berada 3,5 KM dari kompleks Kantor Pemkab Boyolali dan $5 \mathrm{~km}$ dari Jalan Raya Solo-Semarang (Sumber : Solopos 30 Nov 2015). Untuk mencapai lokasi site dari pusat kota (Kompleks Kantor Pemkab Boyolali), pengguna (user) dapat mengaksesnya melalui jalan koroner kota yaitu Jalan Nangka Gumulan, lalu berbelok ke Selatan menuju Jalan Raya Boyolali-Klaten, dan masuk ke dalam jalan utama dusun Indrokilo sejauh 900 Meter dari Jalan Boyolali-Klaten (Gambar 1).

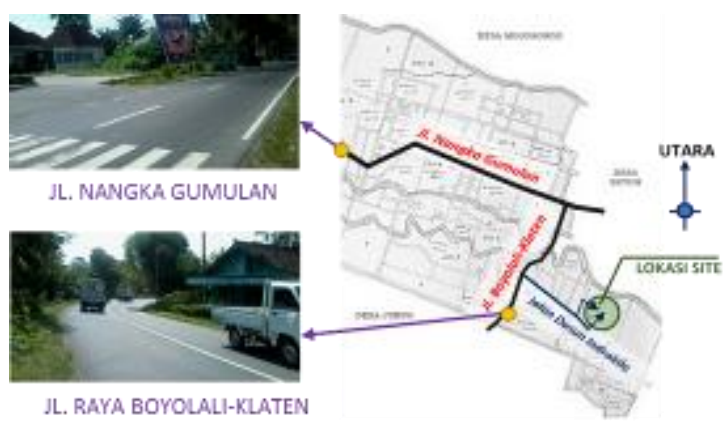

Gambar 1. Pencapaian Makro Menuju Site/tapak Taman Botani

Sumber : Dokumetasi Peneliti , 2017

Berikut ini adalah batas site/tapak Taman Botani Boyolali (Gambar 2.) :

Utara : PT Tirta Amarta Prima, Sungai Sombo, Tegalan

Timur : Tegalan

Selatan : Makam Kraton (Hastana Luhur Ngendrakila Pesarean Pemijen Trah Wiragunan-Prawiranegaran Surakarta), Jalan dusun Indrokilo, Pemukiman warga, TK Pertiwi 2 Kemiri

Barat : Pemukiman warga, Jalan dusun, Tegalan 


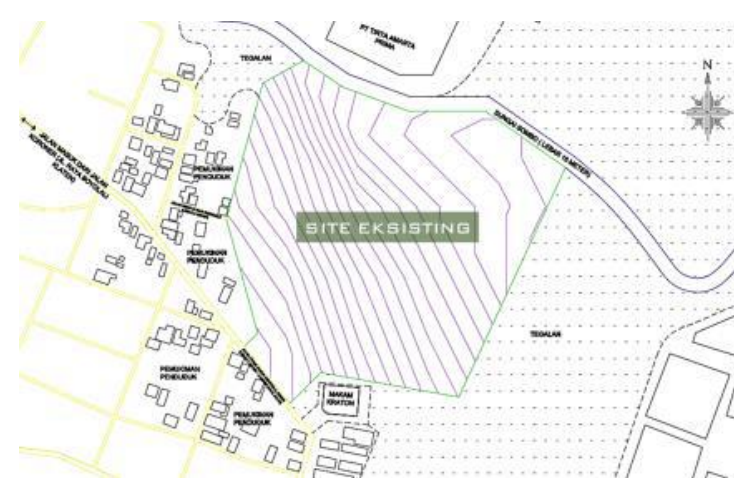

Gambar 2. Site Eksisting Taman Botani Sumber : Dokumentasi Peneliti, 2017

\subsection{Pencapaian}

Tujuan dari analisis pencapaian adalah untuk menentukan Main Entrance (ME) sebagai pintu masuk utama pengunjung dan Side Entrance (SE) sebagai pintu masuk pengelola dan servis sesuai dengan kriteria pencapaian.

Dasar pertimbangan yang digunakan dalam analisis pencapaian adalah : Kondisi eksisting jalan yang berbatasan dengan site (Tabel 2), Pengguna, serta Kriteria dari ME dan SE (Tabel 3).

Tabel 2. Kondisi Eksisting Jalan

\begin{tabular}{|l|l|}
\hline \multicolumn{2}{|c|}{ PENCAPAIAN MIKRO (Gambar 3) } \\
\hline $\begin{array}{c}\text { Jalan Gang Dusun } \\
\text { Indrakilo }\end{array}$ & Jalan Utama Dusun Indrakilo \\
\hline - Intensitas relatif & - Intensitas relatif ramai \\
sepi karena hanya & karena merupakan jalan \\
menuju ke & penghubung utama dusun \\
beberapa rumah & Indrakilo \\
dan tegalan & - Pengguna jalan antara lain : \\
- Pengguna jalan & mobil, truk, sepeda, sepeda \\
antara lain : pejalan & motor, pejalan kaki \\
kaki, sepeda dan & - Memiliki lebar 3 meter \\
sepeda motor, & dengan bahu jalan kanan-kiri \\
- Letak jalan & masing-masing selebar 1 \\
tersembunyi, & meter (total lebar 5 meter) \\
- Memiliki lebar 3 & - Dapat diakses langsung dari \\
meter tanpa bahu & jalan koroner Jl Raya \\
jalan. & Boyolali-Klaten \\
\hline
\end{tabular}

Sumber : Analisis Peneliti, 2017

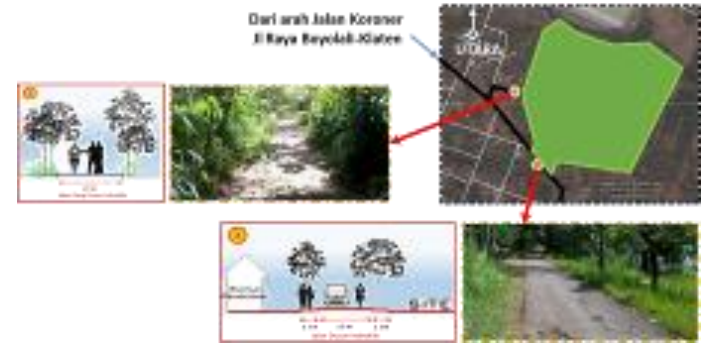

Gambar 3. Pencapaian Mikro Menuju Site Sumber : Dokumentasi Peneliti, 2017

Tabel 3. Kriteria ME dan SE

\begin{tabular}{|l|l|}
\hline \multicolumn{1}{|c|}{ MAIN ENTRANCE } & SIDE ENTRANCE \\
\hline - Menghadap langsung ke arah & - Letak tersembunyi \\
jalan utama, hal ini ditujukan & dari arah \\
untuk mempermudah sirkulasi & datangnya \\
masuk-keluar site. & pengunjung \\
- Mudah dikenali oleh & sehingga hanya \\
pengguna jalan raya, mudah & pengelola dan \\
dicapai dan aman & service yang \\
- Menyesuaikan dengan arah & dapat masuk \\
pergerakan lalu lintas & - Tidak \\
kendaraan di sekitar site dan & menyebabkan \\
tidak menyebabkan & kemacetan \\
kemacetan & - Aman \\
\hline
\end{tabular}

Sumber : Analisis Peneliti, 2017

Berikut adalah hasil analisis pencapaian untuk menentukan Main Entrance (ME) dan Side Entrance (SE) pada Taman Botani Boyolali (Gambar 4) :

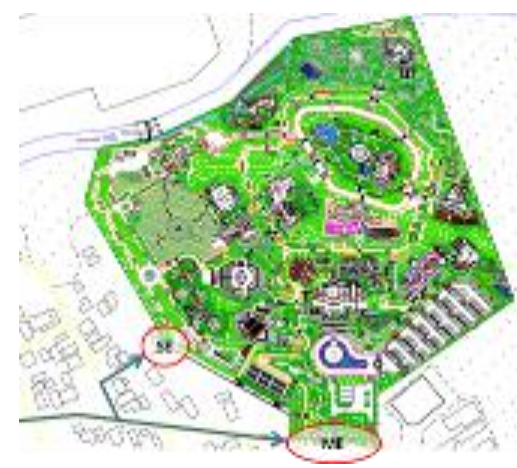

Gambar 4. Posisi Main Entrance (ME) dan Side Entrance (SE) Taman Botani

Sumber : Hasil Analisis Peneliti, 2017

Mengingat bahwa lokasi site Taman Botani cukup tersembunyi, diperlukan suatu penanda (signage) pada pintu masuk dusun Indrakilo seperti sebuah patung, tugu atau monumen yang dapat menunjukan bahwa lokasi Taman Botani dapat diakses melalui jalan tersebut.

Selain itu, diperlukan suatu papan nama (nameplate) yang menunjukkan lokasi Taman Botani dari kejauhan. Papan nama ini dapat digunakan juga 
sebagai sarana penarik perhatian pengunjung. Papan nama Taman Botani Boyolali didesain lebih tinggi dari tinggi rata-rata rumah penduduk sehingga dapat terlihat dari jalan utama dusun Indrakilo (Gambar 5).

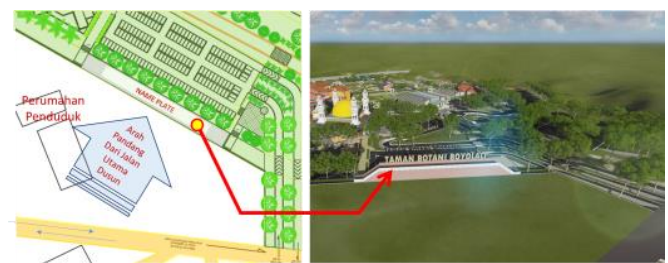

Gambar 5. Nameplate Taman Botani Boyolali Sumber : Hasil Analisis Peneliti, 2017

\subsection{Pemintakatan (Zoning)}

Tujuan dari analisis pemintakatan (Zoning) adalah untuk menentukan perzonaan tapak akhir dan tata massa bangunan pada site.

Dasar pertimbangan yang digunakan dalam analisis pemintakatan adalah Analisis Peruangan dan Analisis Pengolahan Tapak (Analisis pencapaian, Analisis view dan orientasi, Analisis klimatologi serta Analisis kebisingan).

Berdasarkan hasil dari analisis peruangan, zona Taman Botani terbagi menjadi 6 zona kegiatan, yaitu : Zona area parkir (warna merah), Zona kegiatan penerima (warna kuning), Zona kegiatan utama (warna hijau), Zona kegiatan penunjang (warna orange), Zona kegiatan pengelola (warna biru tua), dan Zona kegiatan servis (warna biru muda).

Keenam zona tersebut akan dianalisis terhadap tapak dengan memperhatikan persyaratan dan kebutuhan ruang serta kondisi nyata tapak (pencapaian, view dan orientasi, klimatologi matahari dan angin, serta sumber dan intensitas kebisingan).

Berikut ini adalah hasil perzonaan tapak akhir Taman Botani (Gambar 6) :

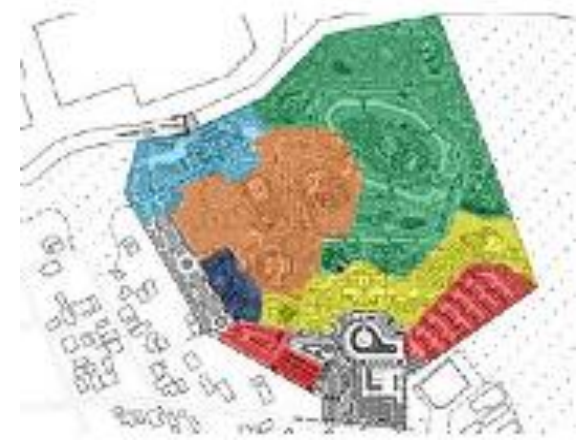

Gambar 6. Perzoningan Akhir Tapak Sumber : Hasil Analisis Peneliti, 2017

\subsection{Tata Massa dan Sirkulasi dalam Site}

\subsubsection{Tata Massa}

Berdasarkan pertimbangan luasan site dan penyebaran akivitas pengguna (terutama pengunjung), konsep massa yang diterapkan pada desain adalah konsep multiple building. Konsep multiple building ini dipilih untuk mencegah terjadinya pemusatan pengunjung pada satu titik area tertentu, yang jika terjadi, dapat menyebabkan pengunjung menjadi tidak tertarik untuk mengeksplorasi site.

Dalam prinsip pendekatan Fun Design, pola tata massa merupakan salah satu elemen pembentuk suasana menyenangkan dalam desain. Pertimbangan pemilihan pola tata massa menitik beratkan pada kesan / impresi menyenangkan yang timbulkan pola. Selain itu, efisiensi terhadap site dan sirkulasi juga perlu diperhatikan (Tabel 4).

Tabel 4. Analisis Tata Massa Radial

\begin{tabular}{|c|l|}
\hline $\begin{array}{c}\text { DASAR } \\
\text { PERTIMBANGAN }\end{array}$ & \multicolumn{1}{c|}{ ANALISIS } \\
\hline $\begin{array}{c}\text { Efisiensi Terhadap } \\
\text { Site }\end{array}$ & $\begin{array}{l}\text { Efisien dalam penyebaran massa } \\
\text { bangunan pada site. }\end{array}$ \\
\hline Sirkulasi & $\begin{array}{l}\text { Sirkulasi berawal dari titik pusat } \\
\text { dan menyebar ke arah luar. Pada } \\
\text { tata massa radial, massa } \\
\text { bangunan tersebar dan } \\
\text { dihubungkan dengan lengan } \\
\text { radial (jari-jari) yang terikat pada } \\
\text { titik pusat. Karena arah } \\
\text { sirkulasinya menyebar keluar, } \\
\text { dapat memudahkan pengunjung } \\
\text { mengeksplorasi site dengan } \\
\text { mudah dan leluasa. }\end{array}$ \\
\hline Aspek Fun Design & $\begin{array}{l}\text { Memiliki kesan yang terarah, } \\
\text { namun lebih bebas dan fleksibel } \\
\text { (tidak mengekang/kaku). Titik }\end{array}$ \\
\hline
\end{tabular}




\begin{tabular}{|c|c|}
\hline $\begin{array}{c}\text { DASAR } \\
\text { PERTIMBANGAN }\end{array}$ & ANALISIS \\
\hline & $\begin{array}{l}\text { pusat pada konfigurasi radial } \\
\text { tidak perlu mendominasi seperti } \\
\text { pada tata masa terpusat. Titik } \\
\text { pusat radial dapat ditentukan dari } \\
\text { point awal yang mengikat lengan- } \\
\text { lengan radialnya sehingga kesan } \\
\text { yang ditimbulkan massa } \\
\text { bangunan tetap sama kuatnya. }\end{array}$ \\
\hline
\end{tabular}

Sumber : Analisis Peneliti, 2017

Berdasarkan pertimbangan tersebut, pola tata massa yang diterapkan pada Taman Botani Boyolali adalah tata massa Radial, dengan massa penerima utama sebagai pusat jari-jari radialnya (Gambar 7).

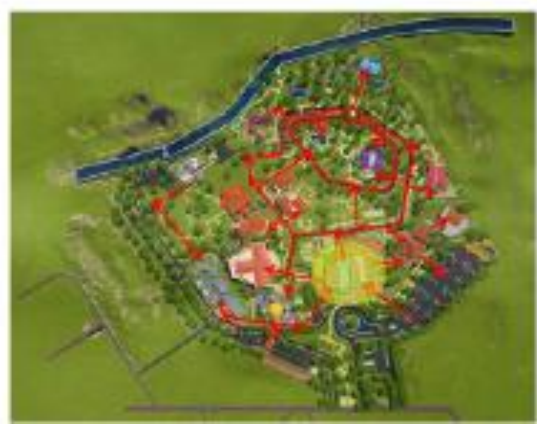

Gambar 7. Sistem Tata Massa Taman Botani Sumber : Hasil Analisis Peneliti, 2017

\subsubsection{Sirkulasi (Pencapaian dalam Site)}

Konsep sirkulasi dan pencapaian pada Taman Botani berfungsi untuk mempermudah akses pengunjung terhadap massa bangunan dan fasilitas yang letaknya tersebar pada tapak. Konsep sirkulasi dalam site dapat juga mempengaruhi pengunjung untuk mengeksplorasi Taman Botani secara maksimal, sehingga sirkulasi didesain dengan mempertimbangkan faktor kemudahan akses, keamanan, serta potensi view tapak (alami dan buatan).

Taman Botani Boyolali yang didesain memiliki besaran tapak yang cukup luas (8 ha), sehingga diperlukan moda transportasi bantuan untuk mencapai titik-titik zona kegiatan apabila pengguna kelelahan berjalan kaki (mengingat bahwa pengunjung Taman Botani berasal dari berbagai golongan usia dan desain tidak boleh mengesampingkan kebutuhan pengguna difabel). Oleh karena itu, konsep sirkulasi dalam site Taman Botani terbagi menjadi 3 berdasarkan modal transportasi pencapaian yang digunakan pengunjung (Tabel 5).

Tabel 5. Sirkulasi Pengunjung dalam Site

\begin{tabular}{|c|c|c|}
\hline Trasportasi & $\begin{array}{c}\text { Jalur } \\
\text { Sirkulasi } \\
\text { Pengunjung } \\
\text { (Gambar 8) }\end{array}$ & Desain \\
\hline $\begin{array}{l}\text { Berjalan } \\
\text { kaki }\end{array}$ & Warna Putih & $\begin{array}{l}\text { Lebar } 1,5 \mathrm{~m} \text { (untuk } \\
\text { sirkulasi dalam zona } \\
\text { kegiatan/fasilitas) dan } \\
\text { lebar } 2 \text { m untuk sirkulasi } \\
\text { keliling site. Perkerasan } \\
\text { berupa batu alam. } \\
\text { Terdapat tempat } \\
\text { berteduh dan istirahat } \\
\text { berupa rain shelter } \\
\text { dibeberapa titik. } \\
\text { Menggunakan ram (sudut } \\
\text { l10) untuk transisi kontur } \\
\text { karena pertimbangan } \\
\text { pengguna anak-anak, } \\
\text { orang tua dan difabel } \\
\text { (Gambar 9). }\end{array}$ \\
\hline $\begin{array}{c}\text { Sepeda dan } \\
\text { Motor } \\
\text { Listrik } \\
\text { (Roda 2, } 3 \\
\text { maupun 4) }\end{array}$ & $\begin{array}{l}\text { Warna } \\
\text { Kuning }\end{array}$ & $\begin{array}{l}\text { Lebar } 3 \text { meter untuk } 2 \\
\text { arah, perkerasan } \\
\text { menggunakan aspal. } \\
\text { Penggunjung yang } \\
\text { membawa sepeda dari } \\
\text { rumah dapat dibawa } \\
\text { masuk berkeliling dalam } \\
\text { site. Terdapat tempat } \\
\text { berteduh dan istirahat } \\
\text { berupa rain shelter } \\
\text { dibeberapa titik. }\end{array}$ \\
\hline $\begin{array}{l}\text { Bus Listrik } \\
\text { dan Motor } \\
\text { Listrik }\end{array}$ & $\begin{array}{l}\text { Warna } \\
\text { Merah }\end{array}$ & $\begin{array}{l}\text { Lebar } 6 \text { meter, dengan } \\
\text { bus pada jalur kiri } \\
\text { selebar } 3 \mathrm{~m} \text { (satu arah) } \\
\text { dan jalur motor listrik } \\
\text { pada jalur kanan selebar } \\
3 \mathrm{~m} \text { ( } 2 \text { arah). }\end{array}$ \\
\hline
\end{tabular}

Sumber : Analisis Peneliti, 2017

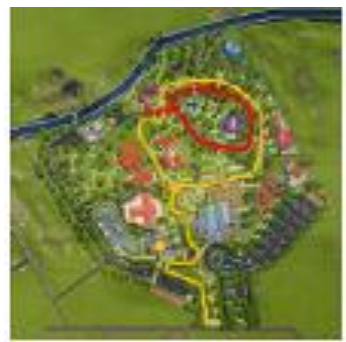

Gambar 8. Jalur Sirkulasi Pengunjung Sumber : Hasil Analisis Peneliti, 2017

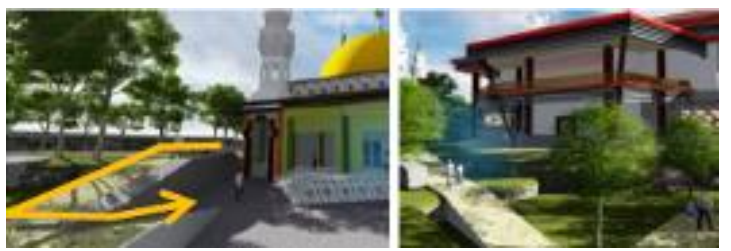

Gambar 9. Ram pada Jalur Pedestrian Sumber : Hasil Analisis Peneliti, 2017 


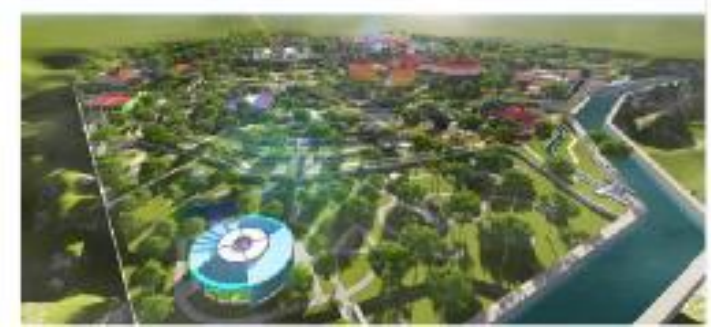

Gambar 10. Konsep Sirkulasi dilihat dari Timur

Sumber : Hasil Analisis Peneliti, 2017

Berdasarkan hasil akhir perzonaan, tata massa bangunan dan sirkulasi, maka diperoleh hasil penataan siteplan seperti berikut (Gambar 11) :

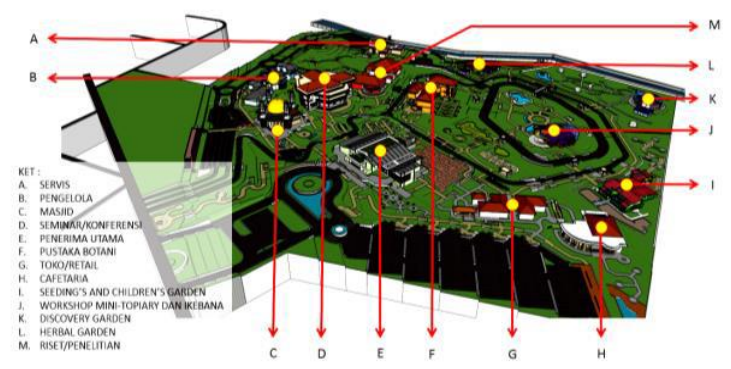

Gambar 11. Hasil Analisis Perzonaan dan Tata Massa Taman Botani

Sumber : Hasil Analisis Peneliti, 2017

\subsection{Zonasi Tematik Tumbuhan Konservasi}

Dalam perancangan suatu Taman Botani, pengelompokan dan penataan unsur vegetasi sangat perlu diperhatikan. Dalam perancangan Taman Botani Boyolali, vegetasi dikelompokkan berdasarkan tema (vegetasi tematik). Penggolongan sesuai tema ini diterapkan dengan tujuan menarik pengunjung untuk menjelajah tiap zona tematik yang tersebar pada tapak.

Zonasi tematik tumbuhan pada desain Taman Botani Boyolali terbagi menjadi 8 zona (Gambar 12).

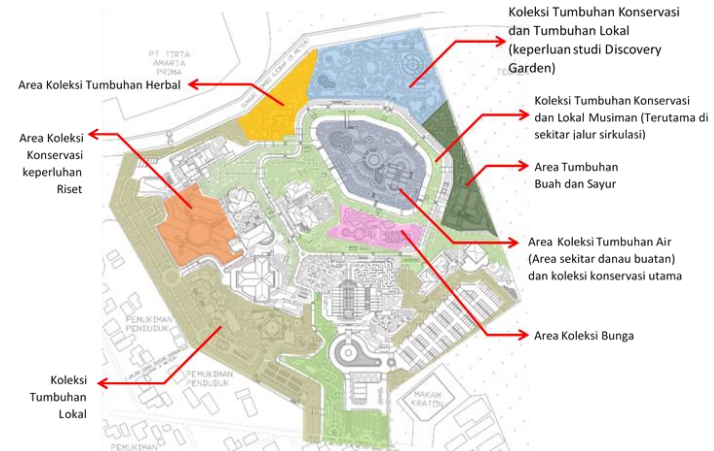

Gambar 12. Zonasi Tematik Tumbuhan Koleksi Taman Botani Boyolali

Sumber : Hasil Analisis Peneliti, 2017

\subsection{Bentuk dan Tampilan \\ 3.7.1 Bentuk}

Bentuk dalam arsitektur dapat mengekspresikan keinginan arsitek pada pengamat / user baik secara langsung maupun tidak langsung.

Dalam perencanaan dan perancangan Taman Botani Boyolali dengan pendekatan Fun Design, kesan / suasana yang ingin disampaikan bangunan pada pengguna adalah suasana penuh kesenangan, semangat serta keceriaan, sehingga bentuk dasar yang akan dipilih memiliki karakteristik yang dapat mewujudkan suasana menyenangkan tersebut (Tabel 6).

Tabel 6. Bentuk Dasar

\begin{tabular}{|c|l|}
\hline BENTUK & \multicolumn{1}{|c|}{ PERTIMBANGAN } \\
\hline Persegi & $\begin{array}{l}\text { Bentuk Persegi dipilih karena } \\
\text { efisiensi dalam pembentukan ruang, } \\
\text { selain itu bentuk ini mudah diolah } \\
\text { dan dikombinasikan } \\
\text { (ditransformasikan) sehingga kesan } \\
\text { monoton persegi dapat berubah } \\
\text { menjadi dinamis. }\end{array}$ \\
\hline Lingkaran & $\begin{array}{l}\text { Bentuk lingkaran dipilih karena garis } \\
\text { lengkung yang memiliki kesan riang } \\
\text { dan dinamis sehingga dapat } \\
\text { membantu terciptanya suasana } \\
\text { menyenangkan dalam ruang. }\end{array}$ \\
\hline Segitiga & $\begin{array}{l}\text { Bentuk segitiga dipilih karena } \\
\text { kesannya yang tajam, aktif, energik } \\
\text { dan berani, sehingga cocol dengan } \\
\text { kesan menyenangkan yang ingin } \\
\text { dicapai bangunan. Selain itu, bentuk } \\
\text { segitiga juga bersifat terarah } \\
\text { sehingga dapat membantu dalam } \\
\text { penunjukan bagi } \\
\text { pengguna/user. arah }\end{array}$ \\
\hline
\end{tabular}

Sumber : Analisis Peneliti, 2017 
Berikut adalah pengapikasian bentuk lingkaran (dominan) pada massa utama kegiatan Discovery Garden Taman Botani Boyolali (Gambar 13) :

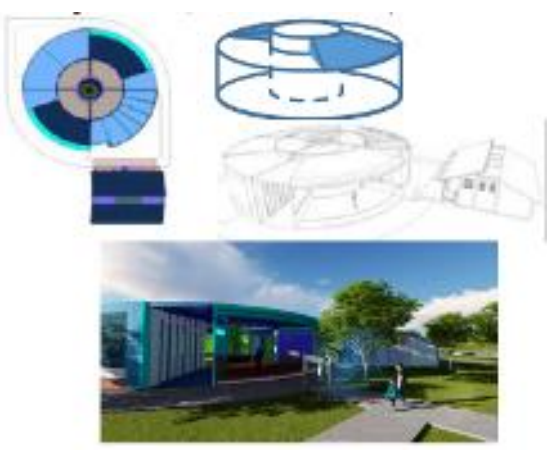

Gambar 13. Penggunaan Bentuk Dasar Lingkaran pada Massa Utama Kegiatan Discovery Garden

Sumber : Hasil Analisis Peneliti, 2017

Penggabungan 2 atau 3 bentuk dasar dapat juga dilakukan untuk meciptakan kesan menyenangkan pada bangunan.

Pada massa utama Seeding's and Children's Garden, bentuk massa mengkombinasikan 2 betuk dasar, yaitu persegi sebagai dasar denah serta segitiga sebagai penutup atap dan kantilever (Gambar 14).
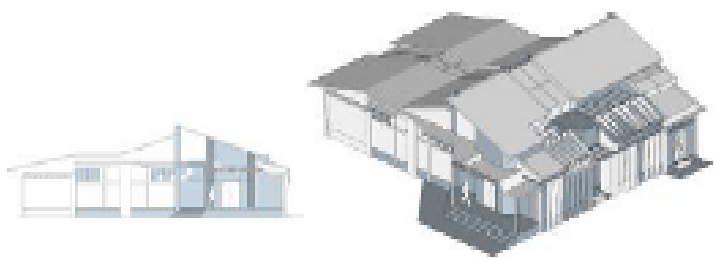

Gambar 14. Penggunaan Kombinasi Bentuk Dasar Persegi dan Segitiga

Sumber : Hasil Analisis Peneliti, 2017

Pada massa utama Herbal Garden dan Workshop Center, desain bangunan mengkombinasikan bentuk dasar lingkaran dan persegi sebagai dasar denah, serta menggunakan bentuk segitiga dan garis lengkung untuk penutup bangunan/ atap (Gambar 15).

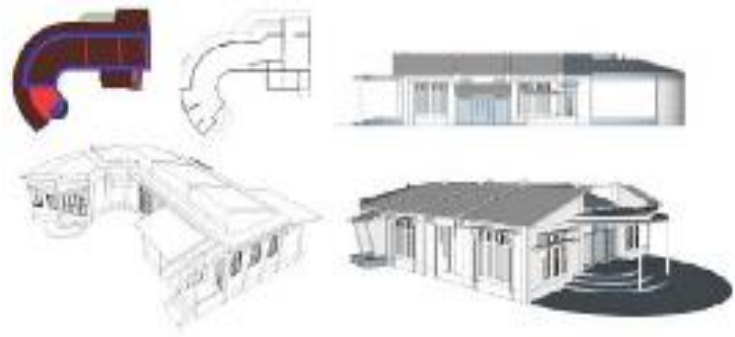

Gambar 15. Penggunaan Penggabungan Bentuk Dasar Persegi, Lingkaran dan Segitiga pada Herbal Garden dan Workshop Center

Sumber : Hasil Analisis Peneliti, 2017

\subsubsection{Tampilan}

Dalam analisis tampilan, terdapat 3 elemen fun design yang menjadi dasar pertimbangan desain, yaitu : Warna, Material, Bukaan dan Pencahayaan.

Warna merupakan suatu elemen yang dapat memberikan efek emosional secara psikologis pada orang yang melihatnya. Warna juga dapat mengkomunikasikan karakter dan suasana dari suatu ruang. Dalam perancangan Taman Botani Boyolali, kesan yang ingin ditimbulkan dan disampaikan pada pengunjung adalah kesan menyenangkan (riang), tidak monoton, dapat membangkitkan semangat (energik), tenang dan menyegarkan, serta bebas.

Dasar pertimbangan yang dipergunakan untuk menentukan warna adalah jenis kegiatan dan kesan/impresi yang ingin disampaikan pada penggunjung.

Pemilihan warna sangat perlu diperhatikan terutama pada pemilihan warna massa kegiatan utama yang menjadi fokus utama desain Taman Botani Boyolali sebagai pusat sarana edukasi botani.

Kesan yang ingin ditimbulkan oleh massa kegiatan utama antara lain adalah kesan bersemangat, penuh energi, kreatif, dan intektual, sehingga warna yang dipilih adalah warna kuning, biru, merah dan ungu.

Warna Hijau dapat juga dipilih karena merupakan warna sekunder gabungan dari warna kuning dan biru, selain itu, warna hijau juga memberikan 
Atika Dwi Harjanti dkk, Taman Botani Boyolali...

impresi menenangkan, berkembang, kesehatan, harmoni, berjiwa muda, seimbang, tenang, nyaman, cerah, dan agresive.

Warna tiap massa kegiatan utama didesain dengan mengambil satu warna dasar dan dikombinasikan dengan warna turunannya yang masih satu gradasi. Selain itu, untuk menambah kesan kontras, diberi warna berbeda yang menjadi highlight (Tabel 7). Warna dibuat satu tema gradasi untuk memberikan ciri khas khusus tiap massa bangunan.

Tabel 7. Aplikasi Warna

\begin{tabular}{|c|c|c|}
\hline $\begin{array}{c}\text { MASSA KEGIATAN } \\
\text { UTAMA }\end{array}$ & $\begin{array}{c}\text { WARNA } \\
\text { DASAR }\end{array}$ & HIGHLIGHT \\
\hline $\begin{array}{c}\text { Discovery Garden } \\
\text { (Gambar 16 a) }\end{array}$ & Biru-Ungu & $\begin{array}{c}\text { Merah } \\
\text { Maroon }\end{array}$ \\
\hline $\begin{array}{c}\text { Seeding's and } \\
\text { Children's Garden } \\
\text { (Gambar 16 b) }\end{array}$ & Hijau & $\begin{array}{c}\text { Merah } \\
\text { Maroon }\end{array}$ \\
\hline $\begin{array}{c}\text { Workshop Center } \\
\text { (Gambar 16 c) }\end{array}$ & $\begin{array}{c}\text { Orange- } \\
\text { Kuning }\end{array}$ & Ungu \\
\hline $\begin{array}{c}\text { Herbal Garden } \\
\text { (Gambar 16 d) }\end{array}$ & Biru-Ungu & Merah \\
\hline
\end{tabular}

Sumber : Analisis Peneliti, 2017

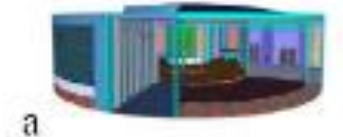

ล

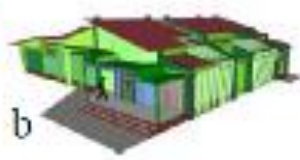

c

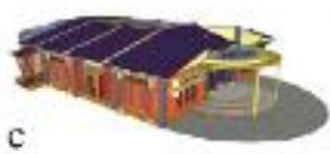

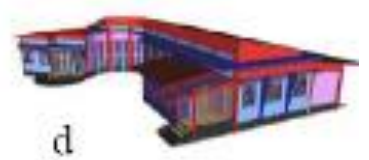

d

\begin{tabular}{|c|c|c|c|}
\hline & MATERIAL & KESAN & KETERANGAN \\
\hline & & & $\begin{array}{l}\text { kaku, namun atap beton } \\
\text { secara struktur lebih } \\
\text { kuat dan kokoh dan } \\
\text { fleksibel untuk } \\
\text { dibentuk ke bentuk } \\
\text { tidak biasa. }\end{array}$ \\
\hline & $\begin{array}{l}\text { Genting } \\
\text { Metalproof }\end{array}$ & $\begin{array}{l}\text { Ringan, } \\
\text { Dinamis } \\
\text { dan } \\
\text { Informal }\end{array}$ & $\begin{array}{lr}\text { Atap } & \text { metalproof } \\
\text { memiliki } & \text { banyak } \\
\text { pilihan warna, sehingga } \\
\text { dapat dikombinasikan } \\
\text { untuk } & \text { menciptakan } \\
\text { kesan riang dan } \\
\text { colorfull } \\
\text { bangunan. Efisien juga } \\
\text { dalam } & \text { pemasangan } \\
\text { karena } & \text { bentuknya } \\
\text { lembaran } & \\
\end{array}$ \\
\hline & Kaca & $\begin{array}{l}\text { Dinamis, } \\
\text { Lapang, } \\
\text { Menarik } \\
\text { Perhatian, } \\
\text { Terbuka } \\
\text { dan Bebas }\end{array}$ & $\begin{array}{lr}\text { Dapat } & \text { memeruskan } \\
\text { cahaya alami } & \text { pada } \\
\text { ruangan } & \text { (skylight) } \\
\text { sehingga } & \text { dapat } \\
\text { membantu } & \text { dalam } \\
\text { pencahayaan } & \text { dan } \\
\text { pembentukan } & \text { suasana } \\
\text { ruang. } & \\
\end{array}$ \\
\hline \multirow{4}{*}{ 혈 } & $\begin{array}{c}\text { Bata } \\
\text { Ekspose }\end{array}$ & $\begin{array}{l}\text { Praktis, } \\
\text { Alami, } \\
\text { dan } \\
\text { Natural }\end{array}$ & $\begin{array}{l}\text { Bata ekspose memiliki } \\
\text { kesan natural dan alami } \\
\text { yang cocok dan sesuai } \\
\text { dengan lingkungan } \\
\text { alami Taman Botani }\end{array}$ \\
\hline & $\begin{array}{l}\text { Batu Alam } \\
\text { (lapis) }\end{array}$ & $\begin{array}{l}\text { Alami dan } \\
\text { Informal }\end{array}$ & $\begin{array}{l}\text { Memiliki kesan alami / } \\
\text { natural yang cocok } \\
\text { dengan lingkungan } \\
\text { hijau taman botani. }\end{array}$ \\
\hline & $\begin{array}{l}\text { Glass Block } \\
\text { Warna }\end{array}$ & $\begin{array}{l}\text { Dinamis, } \\
\text { Mewah, } \\
\text { Menarik } \\
\text { Perhatian, } \\
\text { Terbuka } \\
\text { dan Bebas }\end{array}$ & $\begin{array}{l}\text { Kesan terbuka dan } \\
\text { bebas cocok dengan } \\
\text { kesan Fun Design. } \\
\text { Selain itu, dinding kaca } \\
\text { memiliki banyak } \\
\text { pilihan bentuk dan } \\
\text { warna sehingga sengat } \\
\text { membantu dalam } \\
\text { pembentukan suasana } \\
\text { menyenangkan } \\
\text { (fleksibel karena } \\
\text { suasana yang terbentuk } \\
\text { sesuai dengan cahaya } \\
\text { yang diteruskan dari } \\
\text { warna kaca) }\end{array}$ \\
\hline & $\begin{array}{c}\text { Soft } \\
\text { Material }\end{array}$ & $\begin{array}{l}\text { Lembut, } \\
\text { Hangat, } \\
\text { Welcome }\end{array}$ & $\begin{array}{l}\text { Untuk interior dalam } \\
\text { ruang pada dinding } \\
\text { foyer maupun ruang } \\
\text { tunggu lobby karena } \\
\text { memiliki kesan yang } \\
\text { Welcome dan hangat. }\end{array}$ \\
\hline \multirow[t]{2}{*}{ 营 } & Granite & $\begin{array}{l}\text { Mewah, } \\
\text { Kuat, } \\
\text { Formal } \\
\text { dan } \\
\text { Agung }\end{array}$ & $\begin{array}{l}\text { Material lantai dari } \\
\text { granit tile memiliki sifat } \\
\text { yang Megah dan agung } \\
\text { yang cocok untuk } \\
\text { ditempatkan pada } \\
\text { ruang yang ingin } \\
\text { dipamerkan secara } \\
\text { visual. Granit tile ini } \\
\text { lebih praktikal jika } \\
\text { digunakan walau kesan } \\
\text { yang diberikan tidak } \\
\text { sesuai dengan kesan } \\
\text { yang ingin disampaikan } \\
\text { pendekatan fun design. }\end{array}$ \\
\hline & Kayu & $\begin{array}{l}\text { Hangat, } \\
\text { Lunak, } \\
\text { Elegan, }\end{array}$ & $\begin{array}{l}\text { Lantai dengan material } \\
\text { kayu memiliki kesan } \\
\text { yang alami, natural dan }\end{array}$ \\
\hline
\end{tabular}

Tabel 8. Analisis Material

\begin{tabular}{|c|c|c|c|}
\hline MATERIAL & KESAN & \multicolumn{2}{|c|}{ KETERANGAN } \\
\hline$\nsubseteq$ & Dak Beton & $\begin{array}{c}\text { Kokoh, } \\
\text { Masif }\end{array}$ & $\begin{array}{l}\text { Walau kesan yang } \\
\text { ditimbulkan terkesan }\end{array}$ \\
\hline
\end{tabular}

Sumber : Hasil Analisis Peneliti, 2017

Selain warna, pemilihan material juga berpengaruh pada pembentukan suasana yang menyenangkan. Jenis material yang berbeda dapat memberikan kesan/impresi yang berbeda-beda pula.

Berdasarkan pertimbangan efisiensi pengaplikasian serta kesan/impresi tiap material, berikut adalah material yang diterapkan dalam desain Taman Botani Boyolali (Tabel 8) : 


\begin{tabular}{|c|c|c|}
\hline MATERIAL & KESAN & KETERANGAN \\
\hline & $\begin{array}{c}\text { Natural, } \\
\text { Alami, } \\
\text { Rustic dan } \\
\text { Menyegar } \\
\text { kan }\end{array}$ & $\begin{array}{l}\text { rustik sehingga akan } \\
\text { harmonis dengan } \\
\text { lingkungan alam Taman } \\
\text { Botani. Selain itu, kesan } \\
\text { menyegarkan dari } \\
\text { elemen kayu dapat } \\
\text { membantu user untuk } \\
\text { berelaksasi. }\end{array}$ \\
\hline Batu Alam & $\begin{array}{c}\text { Alami dan } \\
\text { Informal }\end{array}$ & $\begin{array}{lr}\text { Lantai dengan material } \\
\text { batu alam memiliki sifat } \\
\text { informal yang juga } \\
\text { berkesan } \\
\text { sehingga cocok untuk } \\
\text { menciptakan } & \text { area } \\
\text { outdoor/terbuka. Lantai } \\
\text { batu alam dapat } \\
\text { digunakan sebagai } \\
\text { penunjuk jalan pada } \\
\text { rute sirkulasi Taman } \\
\text { Botani karena dapat } \\
\text { memberikan kesan } \\
\text { menyenangkan dan } \\
\text { penuh petualangan } \\
\text { sepanjang jalur. }\end{array}$ \\
\hline $\begin{array}{c}\text { Paving / } \\
\text { Grass Block }\end{array}$ & - & \begin{tabular}{lr} 
Paving & \multicolumn{2}{c}{ Block/Grass } \\
Blok bersifat & netral, \\
namun kesan & visual \\
yang menyenangkan \\
dan unik & dapat \\
dimunculkan & melalui \\
penataan & pola \\
pemasangan. & Pola-pola \\
unik dengan & warna- \\
warna tertentu & dapat \\
membantu & \\
memunculkan & kesan \\
meyenangkan & yang \\
sesuai & dengan \\
pendekatan fun design.
\end{tabular} \\
\hline
\end{tabular}

Sumber : Analisis Peneliti, 2017

Material-material yang telah dipilih akan disesuaikan dengan tema warna dasar tiap massa bangunan (sesuai dengan konsep warna Fun Design) sehingga dapat membantu terciptanya suasana ruang yang menyenangkan (Gambar 17).

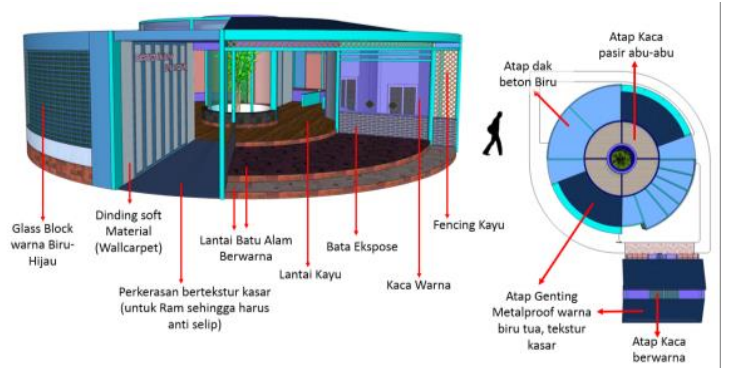

Gambar 17. Penerapan Warna dan Material pada Massa Utama Discovery Garden Sumber : Hasil Analisis Peneliti, 2017
Dalam analisis tampilan, elemen bukaan dan pencahayaan juga mempengaruhi pembentukan suasana menyenangkan dalam ruang. Konsep pencahayaan yang menyenangkan dapat dilakukan secara alami maupun buatan.

Konsep pencahayaan yang menyenangkan secara alami dapat dilakukan dengan cara menggunakan material penutup bukaan dengan kaca berwarna-warni. Sinar yang masuk akan diteruskan kedalam ruang setelah melewati kaca warna, sehingga warna cahaya yang masuk akan sesuai dengan warna kaca tersebut.

Cahaya warna-warni ini dapat memberikan kesan ramai, riang, ceria, sesuai dengan warna-warna yang sesuai dengan pendekatan Fun Design (Gambar 18).

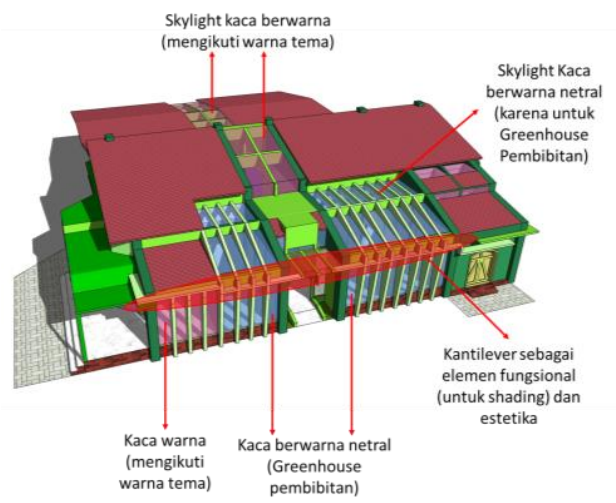

Gambar 18. Aplikasi Konsep Bukaan dan Pencahayaan Alami pada Massa Utama Seeding's and Children's Garden Sumber : Hasil Analisis Peneliti, 2017

Sedangkan, untuk menghasilkan konsep pencahayaan buatan yang menyenangkan pada ruang, hal yang dapat dilakukan adalah dengan cara mengaplikasikan sistem pencahayaan Accent Lighting pada dinding bangunan serta pencahayaan tidak langsung / Indirect Lighting pada plafond dengan cahaya lampu berwarna (Gambar 19). 


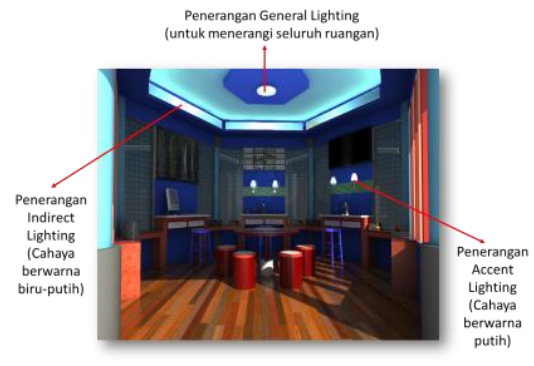

Gambar 19. Penerapan Konsep Pencahayaan Buatan Pada Discovery Room Sumber : Hasil Analisis Peneliti, 2017

\subsection{Struktur}

Tujuan dari analisis sistem struktur adalah untuk memperoleh jenis struktur bangunan yang tepat untuk diterapkan dan diaplikasikan pada bangunan dengan mempertimbangkan faktor kekuatan dan estetikanya.

Desain massa bangunan pada Taman Botani memiliki ketinggian 1-2 lantai (termasuk dalam katagori bangunan bertingkat rendah), sehingga struktur dan konstruksi bangunannya dituntut untuk bisa mengakomodasi kebutuhan tersebut. Dalam analisis struktur, struktur bangunan pada dasarnya terbagi menjadi tiga sistem utama, yaitu : Sub Structure, Super Structure dan Upper Structure.

Berikut adalah sistem struktur yang digunakan dalam desain Taman Botani Boyolali (Tabel 9) :

Tabel 9. Sistem Struktur

\begin{tabular}{|c|l|}
\hline SISTEM STRUKTUR & \multicolumn{1}{|c|}{ DESAIN (Gambar 20) } \\
\hline \multirow{3}{*}{ Sub Structure } & $\begin{array}{l}\text { Rata-rata bangunan } \\
\text { menggunakan atap dengan } \\
\text { rangka truss frame baja } \\
\text { ringan dan atap dak beton } \\
\text { bertulang. }\end{array}$ \\
\hline Super Structure & $\begin{array}{l}\text { Menggunakan sistem struktur } \\
\text { rangka dengan beton } \\
\text { bertulang. }\end{array}$ \\
\hline Upper Structure & $\begin{array}{l}\text { Menggunakan pondasi } \\
\text { footplate untuk kolom utama } \\
\text { dan pondasi menerus batu } \\
\text { kali. }\end{array}$ \\
\hline
\end{tabular}

Sumber : Analisis Peneliti, 2017

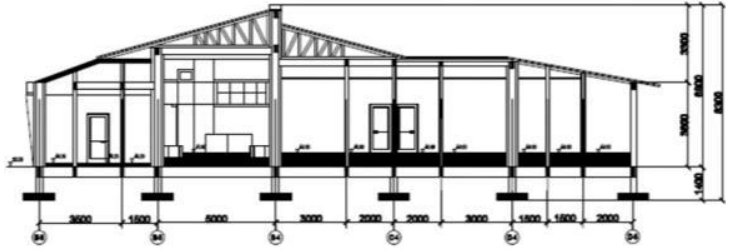

Gambar 20. Penerapan Sistem Struktur pada Desain

Sumber : Hasil Analisis Peneliti, 2017

\subsection{Utilitas}

Tujuan utama dari analisis sistem utilitas adalah untuk menentukan kelengkapan dasar fisik Taman Botani Boyolali agar dapat beroperasi dan berfungsi sebagai kesatuan jaringan internal bangunan maupun kawasan.

Dasar pertimbangan yang dipergunakan dalam menentukan sistem utilitas antara lain adalah :

- Kemudahan dalam penggunaan, distribusi dan pemeliharaan

- Kesederhanaan jaringan sistem utilitas

- Kecilnya faktor resiko crossing antar jaringan

- Keamanan instalasi terhadap pengguna bangunan

- Ketersediaan daya dukung lingkungan terhadap tapak dan bangunan yang direncanakan

- Tidak menimbulkan kerusakan pada lingkungan sekitar tapak

- Jenis-jenis kegiatan yang membutuhkan instalasi utilitas tertentu

Analisis utilitas bangunan terdiri atas berbagai macam sistem dan jaringan yang berfungsi untuk membantu Taman Botani Boyolali agar dapat beroperasi sebagaiman mestinya. Sistem utilitas tersebut antara lain adalah :

\subsubsection{Sistem Jaringan Air Bersih}

Sumber air bersih berasal dari sumur dalam (Deep Well) dan air hujan, sedangkan sumber air untuk keperluhan konservasi (untuk pengairan) berasal dari sungai Sombo.

Air yang bersumber dari sumur 
dalam tidak perlu dilakukan treatment karena air sudah layak, sedangkan untuk air bersih yang berasal dari air hujan, perlu dilakukan treatment terlebih dahulu sebelum digunakan untuk keperluhan air bersih Taman Botani.

Sistem distribusi air yang digunakan adalah sistem distribusi up-feed (untuk semua massa bangunan kecuali massa kegiatan penunjang yang menggunakan sistem distribusi down-feed).

Untuk sumber air yang berasal dari Sungai Sombo, melihat bahwa sungai hanya memiliki debit air yang sedikit apabila sedang tidak dalam musim hujan, maka sistem hanya berfungsi ketika debit air mencukupi (kira-kira 6 bulan dalam 1 tahun). Air dari sumber ini perlu difilter dan ditreatment terlebih dahulu.

\subsubsection{Sistem Jaringan Air Kotor}

Sumber limbah berasal dari air bekas kamar mandi (cuci-mandi), air bekas wastafel, limbah dapur, limbah toilet dan air hujan. Dalam konsep utilitas jaringan air kotor Taman Botani Boyolali, tiap massa bangunan memiliki sistem pengolahan limbah (IPAL) maupun sumur resapan individu.

Sistem ini diterapkan dengan mempertimbangkan luasan site/tapak Taman Botani yang tergolong cukup luas, sehingga jika sistem digabung menjadi satu, akan menjadi tidak efisien.

\subsubsection{Sistem Jaringan Listrik}

Sistem jaringan listrik adalah suatu sistem jaringan dan distribusi pelayanan penyediaan daya listrik dari sumber listrik utama untuk di salurkan ke jaringan internal/mikro suatu bangunan/kawasan.

Sumber listrik yang digunakan pada sistem jaringan listrik Taman Botani Boyolali antara lain berasal dari PLN sebagai sumber daya listrik utama dan Genset sebagai sumber daya listrik darurat (ketika listrik PLN tidak dapat berfungsi).

Taman Botani Boyolali menggunakan sumber listrik yang diperoleh dari PLN menggunakan Jaringan Tegangan Menengah (JTM) 20kV. Listrik yang disalurkan dari JTM akan didistribusikan ke panel distribusi tegangan rendah utama setelah melalui transformator penurun tegangan. Listrik dari panel distribusi utama akan dibagi kedalam beberapa sub-panel untuk didistribusikan ke tiap bangunan dan keperluan kelistrikan pada lingkungan dalam site.

Besar daya yang diperlukan dalam sistem operasional Taman Botani Boyolali sekitar $20 \mathrm{~kW}$ (untuk kebutuhan operasional bangunan dan lingkungan Taman Botani).

\subsubsection{Sistem Pengolahan Sampah}

Pada Taman Botani Boyolali yang akan dirancang, sampah yang paling banyak diproduksi adalah sampah organik yang berasal dari daun-daun serta ranting tumbuh-tumbuhan konservasi. Oleh karena itu, sampah organik tersebut akan dimanfaatkan sebagai bahan baku pembuatan kompos yang akan diajarkan pada anak-anak pada program Childrens and Seedings Garden. Kompos yang terproduksi nantinya akan dijadikan souvenir program, digunakan untuk memupuk tumbuhan koleksi Taman Botani, maupun dijual untuk pengunjung umum.

Berikut adalah skema sistem pengolahan sampah pada Taman Botani Boyolali (Gambar 21) :

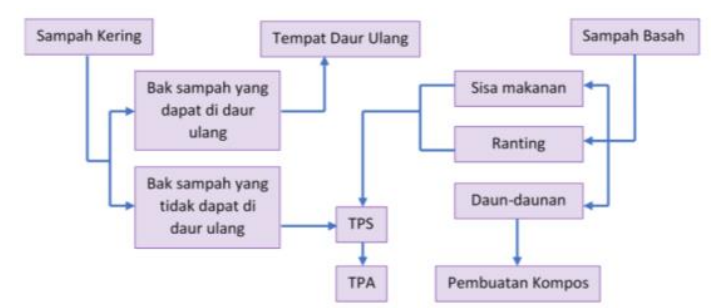

Gambar 21. Skema Sistem Pengolahan Sampah Taman Botani Boyolali Sumber : Hasil Analisis Peneliti, 2017

\section{KESIMPULAN}

Konsep perancangan Taman Botani Kota Boyolali berfokus pada penekanan fungsinya sebagai pusat wisata edukasi 
tumbuh-tumbuhan dengan menerapkan pendekatan Fun Design sebagai metoda pemecahan masalah.

Dalam pendekatan Fun Design, pembentukan kesan / impresi menyenangkan pada suasana ruang sangat perlu diperhatikan. Ini dikarenakan, suasana ruang yang menyenangkan dapat menciptakan iklim pembelajaran yang kondusif sehingga informasi baru akan lebih mudah terekam kedalam otak.

Terdapat 5 elemen pendekatan Fun Design yang dapat membantu dalam pemembentukan suasana menyenangkan dalam desain Taman Botani, yaitu : Bentuk, Material, Warna, Bukaan dan Pencahayaan, serta Tata Massa Bangunan.

Dalam penentuan desain terhadap lima elemen Fun Design diatas, pertimbangan pembentukan kesan / impresi menyenangkan (riang, penuh semangat, cerah, dsb) sangat perlu diperhatikan.

Dari hasil analisis dan korelasi data yang telah dijabarkan sebelumnya, maka diperoleh hasil berupa rancangan Taman Botani Kota Boyolali sebagai Pusat Wisata Edukasi Botani dangan Pendekatan Desain yang Menyenangkan (Fun Design) sebagai berikut :

$\begin{array}{ll}\text { Nama } & : \text { Taman Botani Boyolali } \\ \text { Lokasi } & : \text { Dusun Indrakilo, Desa } \\ & \text { Kemiri, Kecamatan } \\ & \text { Mojosongo, Kabupaten } \\ & \text { Boyolali. } \\ \text { Luas lahan } & : 89,945 \mathrm{~m} 2 \\ \text { Luas Bangunan } & : 31,246.5 \mathrm{~m} 2 \\ \text { Daya Tampung } & : 2219 \text { Orang } \\ \text { Kegiatan } & : \text { Wisata Edukasi Botani }\end{array}$

Hasil penataan kawasan Taman Botani Boyolali menekankan pada konsep sirkulasi dan pola tata massa bangunan yang dapat menstimulus pengunjung untuk mengeksplorasi site secara maksimal. Tata massa yang digunakan adalah tata massa radial yang memiliki kesan/impresi bebas dan fleksibel namun tetap terarah (karena memiliki lengan radial yang menjadi dasar alur sirkulasi) sehingga memudahkan pengunjung untuk mengakses fasilitas Taman Botani namun tetap bebas dan tidak mengekang (Gambar 22).

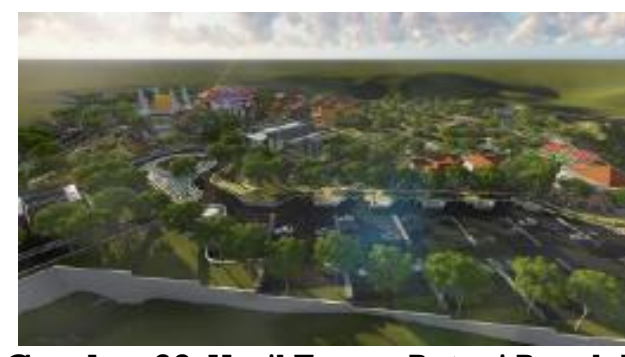

Gambar 22. Hasil Taman Botani Boyolali Sumber : Hasil Analisis Peneliti, 2017

Dalam peranannya sebagai pusat wisata edukasi botani, terdapat lima program kegiatan utama yang menjadi fokus desain, yaitu : Discovery Garden (Gambar 23), Seeding's and Children's Garden (Gambar 24), Herbal Garden (Gambar 25), Workshop Mini-Topiary dan Ikebana (Gambar 26) serta Growth Emulation Alley. Desain kelima massa kegiatan utama tersebut menitik beratkan pada pembentukan suasana menyenangkan berdasarkan 4 elemen Fun design (Bentuk, Warna, Material, Bukaan dan Pencahayaan).

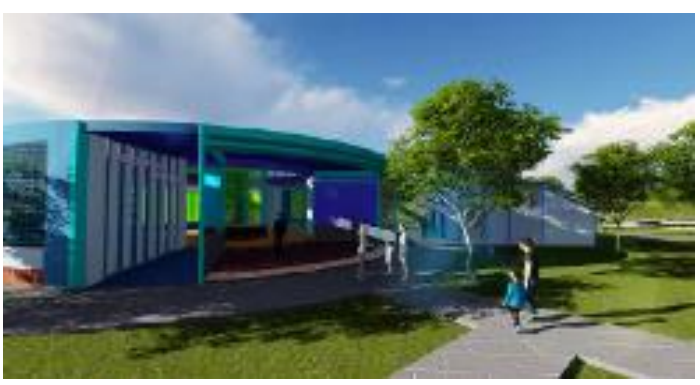

Gambar 23. Discovery Garden Sumber : Hasil Analisis Peneliti, 2017

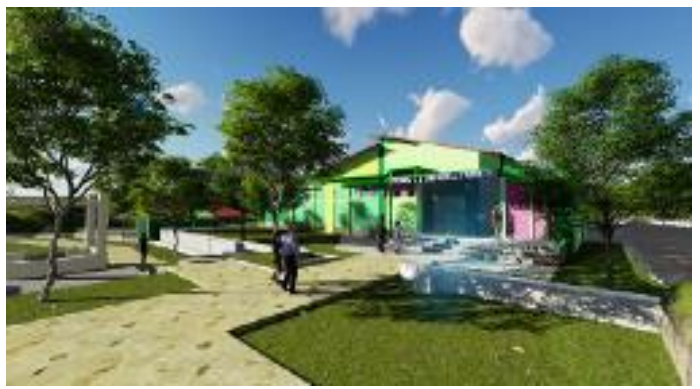

Gambar 24. Seeding's and Children's Garden Sumber : Hasil Analisis Peneliti, 2017 


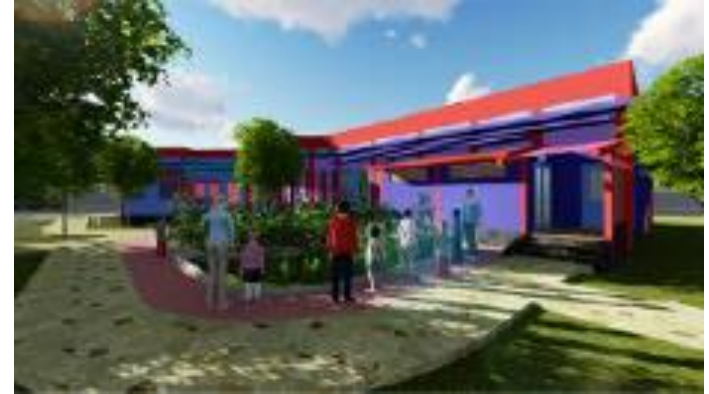

Gambar 25. Herbal Garden Sumber : Hasil Analisis Peneliti, 2017

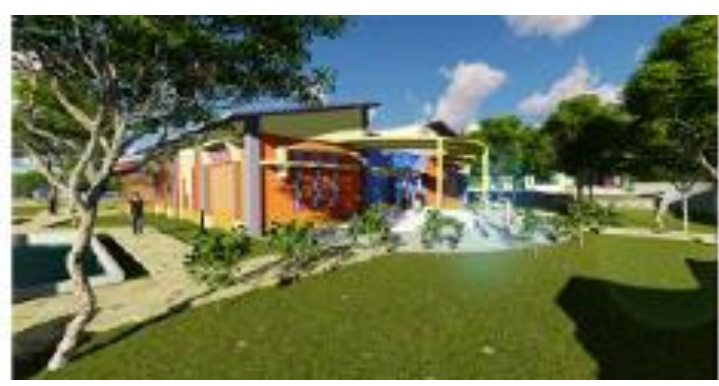

Gambar 26. Workshop Mini-Topiary dan Ikebana

Sumber : Hasil Analisis Peneliti, 2017

\section{REFERENSI}

Abercrombie,Stanley. 1984. Architecture As Art : An Esthetic Analysis.Michigan : Van Nostrand Reinhold

Al Wakhidah, Hijriyah. 2015. Bupati Berencana Bangun Kebun Raya Senilai Rp15 Miliar retrieved 22 November, 2016 from http://www.solopos.com/2015/06/1 1/pembangunan-boyolali-bupatiberencana-bangun-kebun-rayasenilai-rp15-miliar-613384

DePorter, Bobbi ; Hernacki, Mike. 1992. Quantum Learning : Unleashing the Genius in You. New York : Dell Publishing

DK Ching, Franchis. 1996. Arsitektur : Bentuk, Ruang dan Tatanan Edisi kedua. Jakarta: Erlangga

Honggowidjaja, S.P. n.d. Pengaruh Signifikan Tata Cahaya Pada Desain Interior. Retrieved 22 November, 2016 from :

http://puslit.petra.ac.id/journals/int erior/

Jos,Boys. 2010. Towards Creative Learning Spaces : Re-thinking the

Architecture of Post-Compulsory Education. Routledge

Linschoten,J ; Drs Mansyur. 1983. Pengantar Ilmu Jiwa Fenomenologi. Bandung: Jemmars

Suptandar, J.Pamudji. 1999. Desain Interior: Pengantar Merencana Interior untuk Mahasiswa Desai dan Arsitektur. Jakarta : Djambatan

Willis, Judy. 2006. Research Based Strategies to Ignite Student Learning : Insight from a Neurologist and Classroom Teacher. Alexandria, VA: ASCD 